\title{
Modelling biodiesel production from microalgae, using industrial wastewater as a growth medium
}

\author{
Modelación de la producción de biodiesel a partir de microalgas, \\ utilizando aguas residuales industriales como sustrato de crecimiento
}

\author{
Karen Pérez ${ }^{1} \quad$ Danny Ibarra ${ }^{2} \quad$ Miguel Ballen-Segura ${ }^{3 *}$ \\ Recibido 10 de septiembre de 2018, aceptado 16 de agosto de 2019 \\ Received: September 10, 2018 Accepted: August 16, 2019
}

\begin{abstract}
This paper presents a mathematical model validated with experimental data for the analysis of biodiesel production from microalgae biomass, using as an alternative substrate industrial wastewater. System dynamics methodology was used for its development, by which the mathematical model representing the production of biomass and lipids was obtained, as well as the generation of biodiesel from microalgae oil. Biomass generation was represented by a basic growth model which assumes that there is no restriction for nutrients. This biomass generates a quantity of lipids according to the nitrogen-phosphorus ratio present in the industrial effluent, with higher production under low nitrogen concentration. Finally, these lipids are transformed into an amount of fatty acid methyl-ester that varies at a rate of transesterification. Validation and calibration of model behavior, was performed with experimental data obtained in tests of the Scenedesmus sp. microalgae growth in wastewater from the textile and tanning industry. The simulation of the model represented with significant approximation the growth and the generation of lipids for Scenedesmus sp. Furthermore, it was shown that wastewater from tanneries would allow increased production of biodiesel by favoring the generation of biomass rich in amount of lipids. Thus, the proposed model can be a useful tool for assessing the production of biodiesel using industrial wastewater as alternative growth substrates.
\end{abstract}

Keywords: Wastewater, biodiesel, microalgae, modeling.

\section{RESUMEN}

En este trabajo, se presenta un modelo matemático validado con datos experimentales para el análisis de la producción de biodiesel a partir de biomasa microalgal, utilizando como sustrato alternativo aguas residuales industriales. Para su desarrollo se utilizó la metodología de dinámica de sistemas y se obtuvo el modelo matemático que representa la producción de biomasa y lípidos, así como la generación de biodiesel a partir del aceite microalgal. La generación de biomasa fue representada por un modelo básico de crecimiento el cual asume que no existe restricción por nutrientes. Esta genera una cantidad de lípidos en función al ratio nitrógeno-fosforo que presenta el efluente industrial, con mayor producción en condiciones de baja concentración de nitrógeno. Finalmente, estos lípidos son

1 Universidad Cooperativa de Colombia. Facultad de Ingeniería, Programa de Ingeniería Ambiental. Bogotá, Colombia. E-mail: karen.perezs@ucc.edu.co

2 IRCACS-International Research Center for Applied Complexity Sciences. Bogotá, Colombia. E-mail: dwibarrave@unal.edu.co

3 Universidad Sergio Arboleda. Escuela de Ciencias Exactas e Ingeniería. Bogotá, Colombia. E-mail:miguel.ballen@usa.edu.co

* Autor de correspondencia: miguel.ballen@usa.edu.co 
transformados en una cantidad de ácidos grasos metiléster (Biodiesel) que varía en función a una tasa de transesterificación. La validación y calibración del comportamiento del modelo, se llevó a cabo con datos experimentales obtenidos en ensayos de crecimiento de la microalga Scenedesmus sp. En aguas residuales de la industria textil y la industria del curtido de pieles (curtiembres). La simulación del modelo representó con aproximación significativa el crecimiento en aguas residuales y la generación de lípidos para Scenedesmus sp. Así mismo, se evidenció que el agua residual de curtiembres permitiría una mayor producción de biodiesel al favorecer la generación de biomasa rica en cantidad de lípidos. De esta forma el modelo planteado puede ser una herramienta útil para evaluar la producción de biodiesel utilizando aguas residuales industriales como sustratos alternativos de crecimiento.

Palabras clave: Aguas residuales, biodiesel, microalgas, modelamiento.

\section{INTRODUCTION}

Microalgae have been considered as a promising raw material for the production of biofuels due to their high growth rates, shorter lifespans and diversification in their growing conditions [1]. Due to the need of all countries to reduce dependence on fossil fuels which have generated high environmental costs from their extraction to their production, creating instability phenomena in the subsurface, contamination of surface and groundwater, production of greenhouse gases, mainly $\mathrm{CO} 2$, among others [2]. For this work we will take into account the potential of production of biodiesel from microalgae.

Biodiesel is produced mainly through the transesterification of vegetable oils and animal fats [3]. However, its production has been reevaluated, especially in reference to sources of biomass processed. In the first instance, it was proposed to produce it from agricultural crops such as soybeans and corn, among others (first generation biofuel). However, these have the problem of competition with food production of countries and conflicts with land use [4]. Subsequently, it was proposed to produce second generation biofuels from plant material not used for human consumption, such as plant residues, which require high costs for transformation of lignocellulosic material, and require large tracts of fertile land for production [5].

In the last decade microalgae biomass has been proposed as the most promising raw material for the production of Biodiesel (third generation Biofuel). Microalgae are photosynthetic microorganisms using light, $\mathrm{CO} 2$, Nitrogen $(\mathrm{N})$, phosphorus $(\mathrm{P})$ and potassium $(\mathrm{K})$ to grow, they do not require large areas of land to be cultivated, have higher rates of biomass productivity per area compared to traditional energy crops such as corn and soybeans and they can be grown in wastewater decreasing the pressure on freshwater required for food production [6]. Additionally, previous studies have shown that the stress conditions of nutrients can induce significant increases in the lipid content in many species of microalgae [7]. However, despite the many advantages that the use of microalgae can represent, currently their production to industrial scales is economically unviable mainly by costs associated with the substrates used for their growth [8]. Thus, to make optimal use of these microorganisms it has been proposed to use wastewater as alternative substrates for cultivation, since these effluents normally have the concentrations of nutrients, nitrogen and phosphorus needed for growth [9].

Although different authors have experimentally verified the use of industrial wastewater (IWW) for microalgal growth and potential use for the generation of biodiesel [10-12], it has not been established conceptually by any tool to simulate the entire process. Mathematical modeling, in addition to reproducing the dynamics of a phenomenon and predicting it, also serves as a tool for decision making. It can allow, among other things, assessing how feasible is an industrial effluent for microalgae growth and its further processing into biodiesel, optimizing time and expenses, with a high level of certainty.

Building simulation models has different methodologies, one is system dynamics, which suppose a dynamic hypothesis that conceives any aspect of the world as the causal interaction between attributes that describe it [13]. This methodology has been used for example to evaluate the use of 
leachate for the production of microalgae lipids and the removal of heavy metals in a landfill [14]. This article proposes a dynamic model that allows assessing the amount of biodiesel from microalgae generated using industrial wastewater as growth substrate. The model was built with the methodology of system dynamics. Validation and calibration of model behavior, was performed with experimental data obtained in tests of Scenedesmus sp. microalgae growth in wastewater from the textile industry and tanning industry (tanneries).

\section{MATHERIALS AND METHODS}

\section{Development of the model}

The system dynamics methodology was used in developing the model, which supposes a dynamic hypothesis that conceives any aspect of the world as the causal interaction between the attributes that describe it [13]. This development has three stages: Conceptualization, where the key parts of what is desired to be modeled and the interaction between them are identified, given as a result a causal loop diagram, see Figure 1. Formulation, where from the causal diagram, a levels and flows diagram (See Figure 2) and the mathematical formulation are developed. And finally evaluation, where the mathematical model is solved and the correlation between the dynamic hypothesis and the simulation formulated is verified, this in order to verify whether the model is effectively representing the problem that was intended to be modeled [15-16]. Thus a systemic representation was constructed that exists in the microalgae production, lipids and biodiesel respect to the concentration of nitrogen and phosphorous (N:P ratio) in the culture medium.

The biomass is affected by the ratio of nutrients in culture media ( $\mathrm{N}: \mathrm{P}$ ratio). The amount of lipids produced is calculated from the amount of biomass and nutrient levels, by a lipid generating function $\mathrm{F}(r)$. After determining the amount of lipid, the model estimates the number of these that may be transformed into biodiesel according to a transesterification rate given by [17]. Finally, an amount of biodiesel is obtained $\left(B_{o b t}\right)$, which it is compared with a desired amount of biodiesel $\left(B_{d e s}\right)$ through a control variable called difference $(D)$, which aims to adjust the required ratio until the difference is sufficiently small (Figure 1a). Therefore, the model in addition to evaluating the

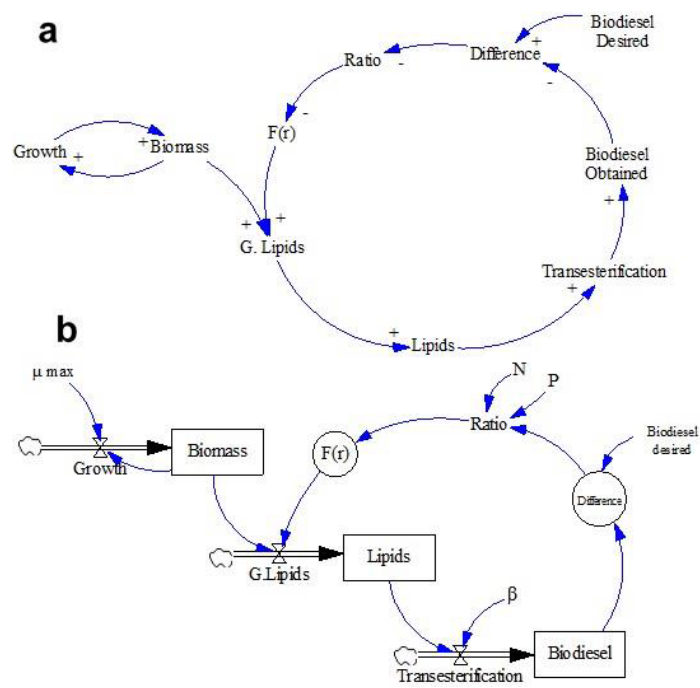

Figure 1. Diagrams of the proposed model to produce microalgal biodiesel using industrial wastewater as a growth substrate. a) Causal loop diagram. b) Levels and flow diagram.

potential of waste water from the nutrient quantity ( $\mathrm{N}: \mathrm{P}$ ratio) for the production of biomass, lipids and subsequent transformation into biodiesel, also adjusts the ratio to the amount of biofuel desired.

Figure 1a shows that there are three attributes that have accumulations in time which are: biomass, lipids and biodiesel. Once the accumulation variables are identified, the level and flow diagram (Figure 1b) was developed.

Finally, from the diagram of levels and flows, the approach of differential equations that constitute the model was developed. The microalgae growth part, was represented using the exponential growth model while the generation of lipids and biodiesel were proposed from the relationships identified by literature review, as mentioned above. The following explains in detail the mathematical formulation of the model.

\section{Biomass}

The model of biomass, starts from the basic model of population growth, based on the assumption of growth with unlimited resources and a growth rate of population proportional to its size. This has been used for modeling different populations such as bacteria, fungi and protists [18]. Therefore, this model for the simulation of microalgal growth in different scenarios was chosen: 


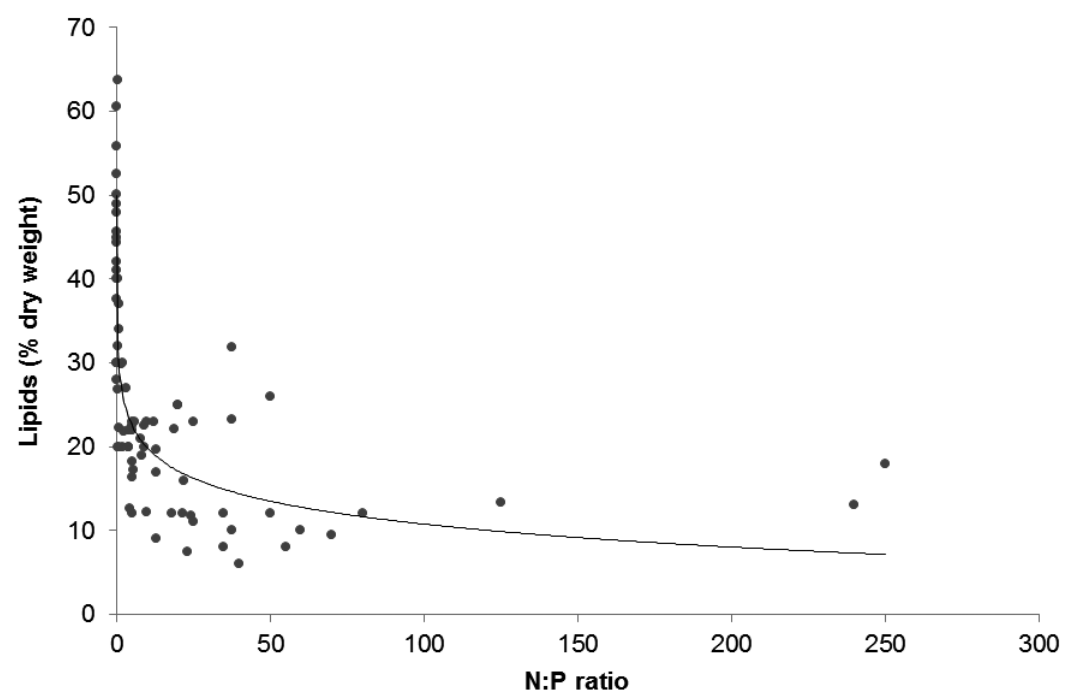

Figure 2. Relationship between lipids content and substrate N:P ratio for Scendesmus genus. $\left(\mathrm{R}^{2}=0,66 ; \mathrm{y}=0,04 \mathrm{LN}(\mathrm{X})+0,2896\right)$.

$$
\frac{d X}{d t}=\mu_{\max } X
$$

where $X$ is the accumulation of microalgae biomass; $\mu_{\max }$ specified growth rate. For $t=0$ in Eq (1) the concentration of microalgae is equal to the initial concentration $\left(X=X_{0}\right)$ meanwhile in $t \neq 0$ the concentration it is given by the integration of $\mathrm{Eq}$ (1) resulting in $\mathrm{Eq}(2)$ :

$$
X(t)=X_{0} e^{\mu \max ^{t}}
$$

\section{Lipids}

Lipid production was determined from the microalgae growth rate $X$ and a lipid generating function, given by a correlation between the N:P ratio and the percentage of lipid by dry weight. The values of this correlation within the genus Scenedesmus sp., reported in other studies are summarized in Figure 2 and Table 1. Increased lipid production in response to nitrogen limitation is observed.

The equation describing the production of lipids is given by:

$$
\frac{d L}{d t}=\int(r) X
$$

Where $L$ is the lipid production rate; $f(r)$ generated function of lipid with $f(r)=-0.04 \ln (r)+0.2896$, $r$ is the $\mathrm{N}: \mathrm{P}$ proportion, which was described by a piecewise function, in which contains the difference control variable, such that: $r=\left\{\begin{array}{l}\frac{N-1}{P} ; D>0 \\ \frac{N}{P} ; \quad D \leq 0\end{array}\right.$ and

$$
\mathrm{D}=B_{d e s}-B_{o b t}
$$

It is noteworthy that the lipid generating function, is independent of the rate of lipid extraction as the data used did not consider the extraction method used. It estimates the percentage of how much lipid by dry weight can be generated depending on the ratio of the sample.

The solution of Eq (3), for a time of $t=0$ corresponds to the initial concentration of lipids containing the microalgae, estimated by multiplying the lipid generator factor function by the initial microalgae concentration $f(r) X_{0}$.

\section{Biodiesel}

Biodiesel production is going to be affected by the rate of transesterification, which varies depending on the selected method. For this case, acid catalyzed transesterification described by [17] was used. Given the above, the equation describing the production of biodiesel is given by: 
Table 1. Data reported of relationship between N:P ratio and dry weight lipids (\%) for Scenedesmus.

\begin{tabular}{|c|c|c|}
\hline Ratio N:P & $\begin{array}{c}\text { Lipids } \\
\text { (\% dry weight) }\end{array}$ & $\begin{array}{c}\text { Study } \\
\text { references }\end{array}$ \\
\hline 23.00 & 7.5 & \multirow{7}{*}{ [19] } \\
\hline 25.00 & 11.0 & \\
\hline 35.00 & 8.0 & \\
\hline 40.00 & 6.0 & \\
\hline 50.00 & 12.0 & \\
\hline 55.00 & 8.0 & \\
\hline 60.00 & 10.0 & \\
\hline 70.00 & 9.5 & \multirow{7}{*}{ [20] } \\
\hline 0.02 & 45.6 & \\
\hline 0.05 & 44.3 & \\
\hline 0.15 & 50.1 & \\
\hline 0.50 & 26.9 & \\
\hline 1.50 & 29.8 & \\
\hline 5.00 & 22.6 & \\
\hline 2.00 & 30.0 & \multirow{9}{*}{ [7] } \\
\hline 4.00 & 22.0 & \\
\hline 5.00 & 23.0 & \\
\hline 8.00 & 21.0 & \\
\hline 10.00 & 23.0 & \\
\hline 12.00 & 23.0 & \\
\hline 20.00 & 25.0 & \\
\hline 20.00 & 25.0 & \\
\hline 50.00 & 26.0 & \\
\hline 0.01 & 45.0 & \multirow{2}{*}{ [21] } \\
\hline 13.00 & 9.0 & \\
\hline 18.10 & 12.1 & \multirow{3}{*}{ [22] } \\
\hline 21.50 & 12.1 & \\
\hline 24.30 & 11.7 & \\
\hline 1.00 & 34.0 & \multirow{7}{*}{ [23] } \\
\hline 3.00 & 27.0 & \\
\hline 5.00 & 22.0 & \\
\hline 9.00 & 20.0 & \\
\hline 13.00 & 17.0 & \\
\hline 22.00 & 16.0 & \\
\hline 35.00 & 12.0 & \\
\hline 2.50 & 21.8 & \multirow{2}{*}{ [24] } \\
\hline 4.52 & 12.7 & \\
\hline 1.00 & 22.3 & \multirow{2}{*}{ [25] } \\
\hline 9.00 & 22.5 & \\
\hline
\end{tabular}

\begin{tabular}{|c|c|c|}
\hline Ratio N:P & $\begin{array}{c}\text { Lipids } \\
\text { (\% dry weight) }\end{array}$ & $\begin{array}{c}\text { Study } \\
\text { references }\end{array}$ \\
\hline 12.82 & 19.7 & \\
\hline 0.01 & 52.6 & \multirow{5}{*}{ [26] } \\
\hline 0.01 & 49.0 & \\
\hline 0.02 & 42.0 & \\
\hline 0.02 & 30.0 & \\
\hline 0.02 & 30.0 & \\
\hline 0.10 & 37.6 & \multirow{4}{*}{ [27] } \\
\hline 5.33 & 12.0 & \\
\hline 80.00 & 12.0 & \\
\hline 240.00 & 13.0 & \\
\hline 18.75 & 22.2 & \multirow{3}{*}{ [17] } \\
\hline 25.00 & 23.0 & \\
\hline 37.50 & 23.3 & \\
\hline 0.10 & 28.0 & \multirow{6}{*}{ [28] } \\
\hline 0.51 & 20.0 & \\
\hline 1.02 & 20.0 & \\
\hline 2.05 & 20.0 & \\
\hline 4.10 & 20.0 & \\
\hline 8.20 & 19.0 & \\
\hline 5.00 & 18.3 & \multirow{4}{*}{ [29] } \\
\hline 5.00 & 16.4 & \\
\hline 5.66 & 17.2 & \\
\hline 37.50 & 31.8 & \\
\hline 0.63 & 32.0 & \multirow{3}{*}{ [30] } \\
\hline 0.63 & 40.0 & \\
\hline 37.50 & 10.0 & \\
\hline 0.01 & 55.9 & \multirow{6}{*}{ [31] } \\
\hline 0.04 & 60.6 & \\
\hline 0.50 & 63.7 & \\
\hline 10.00 & 12.2 & \\
\hline 125.00 & 13.4 & \\
\hline 250.00 & 18.0 & \\
\hline 0.01 & 40.0 & \multirow{5}{*}{ [32] } \\
\hline 0.10 & 48.0 & \\
\hline 0.13 & 41.0 & \\
\hline 1.00 & 37.0 & \\
\hline 4.00 & 20.0 & \\
\hline 6.00 & 23.0 & [33] \\
\hline
\end{tabular}

$$
\frac{d B}{d t}=\beta L
$$

Where $\frac{d B}{d t}$ is the rate of production of biodiesel, $\beta$ the rate of transesterification.

\section{Experimental phase}

For this study, two industrial wastewater were used as substrates for the growth of Scenedesmus sp. microalgae: textile wastewater (TexWW) and tannery wastewater (TanWW). Spot samples were taken of the two industrial effluents without pretreatment; 
their physicochemical characteristics were evaluated in the laboratory according to APHA-AWWA methods (Table 2).

The Scenedesmus sp. microalgae was isolated from a wetland of Bogotá, Colombia, and maintained in a basal medium BBM (Bold Basal Medium) at a temperature of $20^{\circ} \mathrm{C}$ with a $12: 12 \mathrm{~h}$ light cycle. To evaluate the growth of microalgae in each of the waters, a volume of $600 \mathrm{ml}$ of culture was centrifuged (5000 rpm for 5 minutes) and added to $600 \mathrm{ml}$ of industrial effluent (final ratio 1:1) and daily monitored for optical density (absorbance at $660 \mathrm{~nm}$ ) for a period of 15 days in a UV/Visible HACH DR6000 spectrophotometer (for details of the experiments see $[34,35])$. Subsequently, the absorbance values were converted to dr y weight biomass by using the relationship reported by [34]. The biomass obtained in the experiments was centrifuged and oven dried at $70{ }^{\circ} \mathrm{C}$ for 12 hours and lipids were extracted with chloroform-methanol- $\mathrm{NaCl}$ based on the protocol [36] and finally quantified by gravimetry.

\section{RESULTS AND DISCUSSION}

The model proposed in this study was validated with the experimental data from two industrial wastewater (textile and tannery). The parameters used are in Table 3. This validation was performed for the first two levels: production of biomass and lipids while for biodiesel (third level) it was only simulated.

\section{Biomass Production}

In Figure 3, one can observe the biomass values experimentally obtained relative to those simulated for both effluents, presenting a significant adjustment $\left(R^{2}=0.74 p>0.05(\right.$ TexWW $)$ y $R^{2}=0.78, p>$ $0.05(\operatorname{Tan} W W)$ ). In both cases, in the actual data,

Table 2. Characterization of Industrial Wastewater used in this work.

\begin{tabular}{|l|c|r|}
\hline \multicolumn{1}{|c|}{ Parameters } & TexWW & TanWW \\
\hline $\mathrm{pH}$ & 7.68 & 10.14 \\
\hline Conductivity $[\mu \mathrm{S} / \mathrm{cm}]$ & 1482 & 33.6 \\
\hline BOD $\left[\mathrm{mgL}^{-1}\right]$ & 115 & 17363 \\
\hline Inorganic Nitrogen $\left[\mathrm{mgL}^{-1}\right]$ & 351 & 231.6 \\
\hline Phosphates $\left[\mathrm{mgL}^{-1}\right]$ & 157 & 13.23 \\
\hline Sulfates $\left[\mathrm{mgL}^{-1}\right]$ & $>2.5$ & 27.33 \\
\hline
\end{tabular}

Table 3. Parameters and values used for model calibration and validation in this work.

\begin{tabular}{|l|c|c|c|}
\hline \multirow{2}{*}{ Parameters } & \multicolumn{2}{|c|}{ Values } & \multirow{2}{*}{ Study references } \\
\hline \multirow{2}{*}{$\mu_{\max }\left(\mathrm{d}^{-1}\right)$} & 0.034 & $($ TexWW $)$ & \multirow{2}{*}{ Present } \\
\cline { 2 - 3 } & 0.016 & $($ TanWW $)$ & \\
\hline \multirow{2}{*}{$X_{0}\left(\mathrm{~g} \mathrm{~L}^{-1} \mathrm{~d}^{-1}\right)$} & 0.212 & $($ TexWW $)$ & \multirow{2}{*}{ Present } \\
\cline { 2 - 3 } & 0.6 & $($ TanWW $)$ & \\
\hline \multirow{2}{*}{$r=\frac{N}{P}$} & 2.24 & $($ TexWW $)$ & \multirow{2}{*}{ Present } \\
\cline { 2 - 3 } & 17.51 & $($ TanWW $)$ & \\
\hline$f(r)$ & \multicolumn{2}{|c|}{$-0.04 \ln (r)$} & Present \\
\hline$\beta$ & \multicolumn{2}{|c|}{0.131} & {$[17]$} \\
\hline
\end{tabular}

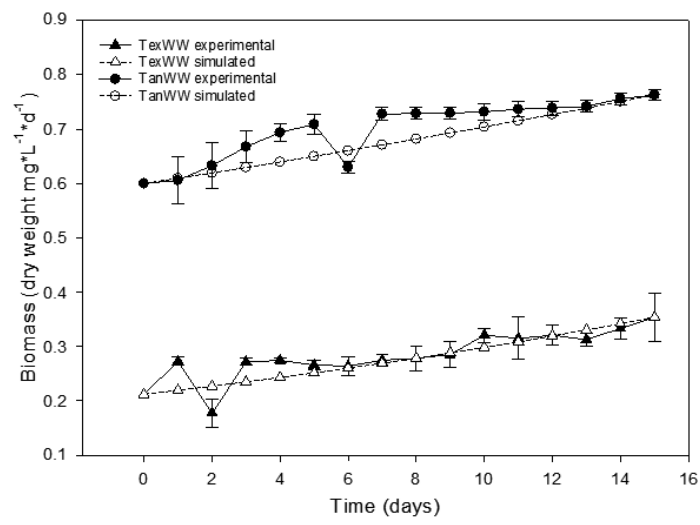

Figure 3. Biomass production of Scenedesmus sp. in TexWW (triangle) and TanWW (circle). Black and white forms are experimental and simulated data respectively.

fluctuations occur during the assessment period, especially in the TexWW, which are not represented by the model. In this paper the model used for biomass generation, is a classic growth model, which only takes into account the maximum rate of growth of the microalgae, without considering additional factors such as nutrient restriction, environmental parameters, bacterial effect, among others, which can generate variations in the growth curve of the microorganism. However, the model selection was based on its simplicity.

Furthermore, the microalgae growth in industrial wastewaters, can be affected by the presence of pollutants such as hydrocarbons and heavy metals. The latter may prevent the proper development of the organism as reported by [37] who observed inhibition of biomass generation on Spirulina sp. 
in the presence of chromium, lead and cadmium in tannery wastewater. These factors can affect punctually the growth patterns of microorganisms but not be reflected in the growth models.

After 15 days of testing, calculation of the maximum rate of icroalgae growth was performed, which resulted in $0.034 \mathrm{~d}^{-1}$ and $0.016 \mathrm{~d}^{-1}$ for TexWW and TanWW respectively. However, the greatest production of biomass was obtained with TanWW reaching a net production of $0.1630 \mathrm{~g} / \mathrm{L}$ compared to $0.1420 \mathrm{~g} / \mathrm{L}$ for TexWW. The ratio presented between inorganic nitrogen and phosphorus (ratio), essential nutrients in microalgae growth, could explain the difference in production between the effluents evaluated. TexWW has a ratio of 2:1 compared to TanWW that presents a ratio of $17: 1$, which is close to that proposed by [38], who found that in marine environments the relationship between these two elements is $16: 1$ and that it is reflected in the internal rate of phytoplankton organisms. Therefore relationships close to 16 , would be the most optimal for microalgae growth. However, it must be noted that nutrient limitation conditions, very high or very low ratios, can cause physiological response of organisms, accumulating metabolites of interest, in this case, increased lipid accumulation. Thus, alternating cultures between sufficiency and deficiency of nutrients have been proposed as strategies to increase the efficiency of generation of biodiesel [4].

\section{Lipids Production}

To assess lipid production using the model, the ratio (N:P) for each residual water (Table 3) was estimated and subsequently the lipid generating function was calculated $f(r)$, which was adjusted to the experimental data obtained, with values of 23.53 to $25.74 \%$ (experimental-simulated) for TexWW and 24.3 to $17.51 \%$ for TanWW and similarly, simulated lipid productivity with respect to experimental was similar, with values of 0.08 to $0.09 \mathrm{~g} / \mathrm{Ld}$ for TexWW and 0.19 to $0.13 \mathrm{~g} / \mathrm{Ld}$ for TanWW (Figure 4).

In this paper the generation of lipid was estimated based on the microalgae (Scenedesmus spp.) and the lipid extraction method used in different works consulted was not considered. This is important to take into account, since the amount of lipids reported for a microalgae species, will depend not only on its actual concentration, but on the extraction efficiency of the method used. The extraction by solvents of [36] y [39], are perhaps the methods most used on the microalgae biomass, differing in the proportions of the solvents used (chloroform: methanol $(\mathrm{v} / \mathrm{v})$ $2: 1$ and 1:2 respectively), but also they exhibit differences in extraction efficiency. [40] reported for $S$. dimorphus a percentage of extracted lipids of $14 \%$ with Folch compared to $6 \%$ with Bligh \& Dyer. Similarly, [41] we observed variations for $C$. vulgaris ranging from 3 to $23 \%$ of lipids depending on the solvent and the proportion used. Thus, differences that may exist between experimental and simulated values (Figure 4) could be due to the efficiencies of extraction of the methods used in the different works consulted.

Despite the differences that may exist resulting from the extraction methods, Figure 2 shows a general trend of decrease in the percentage of lipids in relation to the increase in the N:P ratio, which is contained in the generating function established in this study. This inverse ratio between lipid generation is similar to that reported by $[7,23,28$, 42] who show an accumulation of fatty acid at low concentrations of nitrogen.

Numerous studies have shown that microalgae in conditions of physical or nutritional stress modify their metabolic machinery, generating a greater accumulation of lipids or modifying the composition of the fatty acids $[43,7,44,45]$. Nitrogen is one of the nutrients that has shown the most influence on the metabolism of lipids in microalgae; under

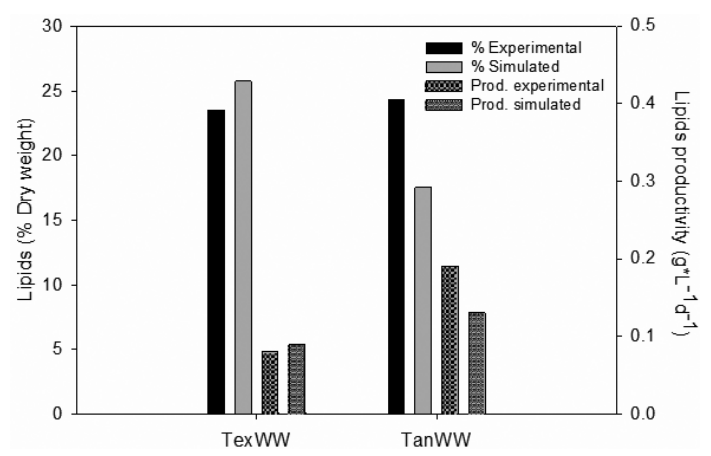

Figure 4. Experimental and simulated values of lipid content and productivity in Scenedesmus sp. growing in industrial wastewater. 
nitrogen limiting conditions, these microorganisms increase the production of neutral lipids, mainly as triglycerides (TAG), which perform functions primarily of energy storage, accumulating densely in the shape of lipid bodies in both cytoplasm and chloroplasts [43].

Finally, based on the results, it is evident that the TanWW allowed a greater production of lipids with potential to be transformed into biodiesel, despite having a lower percentage of generation with respect to TexWW, indicating that production is directly related with the amount of biomass obtained, ie, it is a function that depends on the microalgae growth on the substrate used and of the lipid generating function.

\section{Biodiesel Production}

Figure 5 shows the production of biodiesel obtained by the model resulting in 11.93 and $17.5 \mathrm{mg} / \mathrm{Ld}^{-1}$ for TexWW and TanWW respectively. Therefore, the waste water which proved to be the best substrate for the production of biomass, lipids and subsequently processing into biodiesel is TanWW. Although this study did not carry out the process of obtaining biodiesel, some works such as [24]; [46] productivities of $294 \mathrm{mg} / \mathrm{L}$ and $920 \mathrm{mg} / \mathrm{L}$ in 14 and 16 days of experimentation, for Scenedesmus sp. and Chlollera sp. respectively, using as substrate municipal wastewater. These values are higher than those simulated by the model. However, these differences may be due to the influence that wastewater has in microalgae growth, as the wastewaters used in this study are industrial, which

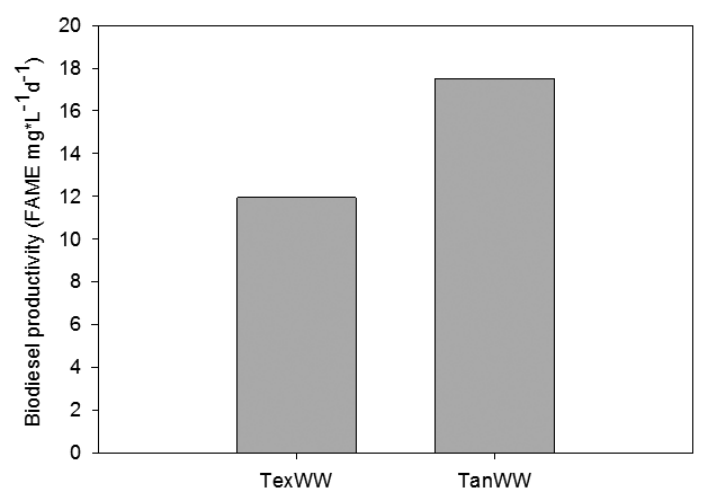

Figure 5. Simulated values obtained from microalgae biodiesel, using industrial wastewater as a growth substrate for Scenedesmus sp. have features such as heavy metals and hydrocarbons, among others, that may affect microalgae growth and therefore generate transesterificable lipids. On the other hand, Chlollera sp. It has been reported to have higher levels of accumulation of lipids than Scenedesmus sp. [47, 48, 4].

\section{CONCLUSIONS}

The mathematical model was adjusted to the experimental results obtained, demonstrating that it can be a valuable predictive tool to assess the feasibility of using microalgae biomass for generating biodiesel, when industrial wastewater is used as growth substrate for the microorganism. Of the evaluated water, TanWW allowed a greater production of biodiesel by favoring generation of biomass with a high amount of lipids. However, further work is needed to evaluate experimentally and adapt the model, the effect it can have on growth, lipid accumulation and presence in the biodiesel, of pollutants such as heavy metals, especially chromium, normally present in this type of effluent. Similarly, further research would be valuable to determine the utility of the model, when applied with other microalgae different to Scenedesmus. This modeling process can be adapted to other sources of biomass, having in count the raw materials and the desired product.

\section{ACKNOWLEDGEMENTS}

We thank to the Sergio Arboleda University for the practical and economical support given to this investigation. Also, we thank to the professor Mr. Luis Eduardo Pérez L. for his contribution to the structure and organization of the document.

\section{REFERENCES}

[1] S. Wang, J. Zhu, L. Dai, X. Zhao, D. Liu and W. Du. "A novel process on lipid extraction from microalgae for biodiesel production". Energy. Vol. 115, Issue 1, pp. 963-968. 2016. URL: https://doi.org/10.1016/j. energy.2016.09.078

[2] M.N. Campbell. "Biodiesel: Algae as a Renewable Source for Liquid". Guelph Engineering Journal. Vol. 1, Issue 1, pp. 2-7. ISSN: 1916-1107. 2008. URL: http://www. 
soe.uoguelph.ca/webfiles/gej/articles/ GEJ_001-002-007_Campbell_Biodiesel_ from_Algae.pdf

[3] Y. Chisti. "Biodiesel from microalgae". Biotechnol Adv. Vol. 25, Issue 3, pp. 294306. 2007. URL: http://doi.org/10.1016/j. biotechadv.2007.02.001

[4] T.M. Mata, A.A. Martins and N.S. Caetano. "Microalgae for biodiesel production and other applications: a review". Renewable Sustainable Energy Rev. Vol. 14, Issue 1, pp. 217-232. 2010. URL: https://doi. org/10.1016/j.rser.2009.07.020

[5] A. Pandey, D.-J. Lee, Y. Chisti and C.R. Soccol. "Biofuels from algae". Newnes. 2013.

[6] A.F. Aravantinou, M.A. Theodorakopoulos and I.D. Manariotis. "Selection of microalgae for wastewater treatment and potential lipids production". Bioresour Technol. Vol. 147, pp. 130-134. 2013. URL: https:// doi.org/10.1016/j.biortech.2013.08.024

[7] L. Xin, H. Hong-Ying, G. Ke and Y.-X. Sun. "Effects of different nitrogen and phosphorus concentrations on the growth,nutrient uptake, and lipid accumulation of a freshwater microalga Scenedesmus sp". Bioresour Technol. Vol. 101, pp. 54945500. 2010. URL: https://doi.org/10.1016/j. biortech.2010.02.016

[8] O. Komolafe, S.B. Velasquez Orta, I. Monje-Ramirez, I. Yañez Noguez, A.P. Harvey and M.T. Orta Ledesma. "Biodiesel production from indigenous microalgae grown in wastewater". Bioresour Technol. Vol. 154, pp. 297-304. 2014. URL: https:// doi.org/10.1016/j.biortech.2013.12.048

[9] J.k. Pittman, A.P. Dean and O. Osundeko. "The potential of sustainable algal biofuel production using wastewater resources". Bioresour Technol. Vol. 102, pp. 17-25. 2011. URL: https://doi.org/10.1016/j. biortech.2010.06.035

[10] S.S.M. Mostafa, E.A. Shalaby and G.I. Mahmoud. "Cultivating Microalgae in Domestic Wastewater for Biodiesel Production". Notulae Scientia Biologicae. Vol. 4, pp. 56-65. 2020. URL: www. notulaebiologicae.ro

[11] S. Chinnasamy, A. Bhatnagar, R.W. Hunt and K. Das. "Microalgae cultivation in a wastewater dominated by carpet mill effluents for biofuel applications". Bioresour Technol. Vol. 101, Issue 9, pp. 3097-3105. 2010. URL: https://doi.org/10.1016/j. biortech.2009.12.026

[12] I. Woertz, A. Feffer, T. Lundquist and Y. Nelson. "Algae grown on dairy and municipal wastewater for simultaneous nutrient removal and lipid production for biofuel feedstock". J Environ Eng. Vol. 135, Issue 11, pp. 11151122. 2009.

[13] J. Sterman. "Business Dynamics: Systems Thinking and Modeling for a Complex World". Irwin/McGraw-Hill. New York. 2000.

[14] R. Richards and B. Mullins. "Using microalgae for combined lipid production and heavy metal removal from leachate". Ecol Modell. Vol. 249, pp. 59-67. 2013. URL: https://doi. org/10.1016/j.ecolmodel.2012.07.004

[15] D. Ibarra, J.M. Redondo and C. Fajardo. "Modeling waste management in a bioethanol supply chain: A system dynamics approach". Dynal. Vol. 83, p. 195. 2016.

[16] J.Aracil y F. Gordillo. "Dinámica de sistemas". Alianza Editorial Madrid. 1997.

[17] S. Mandotra, P. Kumar, M. Suseela and P. Ramteke. "Fresh water green microalga Scenedesmus abundans: a potential feedstock for high quality biodiesel production". Bioresour Technol. Vol. 156, pp. 42-47. 2014. URL: https://doi.org/10.1016/j. biortech.2013.12.127

[18] P. Blanchard, R.L. Devaney and R.H. Glen. "Differential Equations". Boston. 2011.

[19] G.-Y. Rhee. "Effects of N: P atomic ratios and nitrate limitation on algal growth, cell composition, and nitrate uptake". Limnol Oceanogr. Vol. 23, Issue 1, pp. 10-25. 1978. URL: https://doi.org/10.4319/ lo.1978.23.1.0010

[20] M. Piorreck, K.-H. Baasch and P. Pohl. "Biomass production, total protein, chlorophylls, lipids and fatty acids of freshwater green and blue-green algae under different nitrogen regimes". Phytochemistry. Vol. 23, Issue 2, pp. 207 216. 1984. URL: https://doi.org/10.1016/ S0031-9422(00)80304-0

[21] G. Breuer, P.P. Lamers, D.E. Martens, R.B. Draaisma and R.H. Wijffels. "The impact 
of nitrogen starvation on the dynamics of triacylglycerol accumulation in nine microalgae strains". Bioresour Technol. Vol. 124, pp. 217-226. 2012. URL: https:// doi.org/10.1016/j.biortech.2012.08.003

[22] P.J. McGinn, K.E. Dickinson, K.C. Park, C.G. Whitney, S.P. MacQuarrie, F.J. Black, J.-C. Frigon, S.R. Guiot and S.J. O'Leary. "Assessment of the bioenergy and bioremediation potentials of the microalga Scenedesmus sp. AMDD cultivated in municipal wastewater effluent in batch and continuous mode". Algal Research. Vol. 1, Issue 2, 155-165. 2012. URL: https://doi. org/10.1016/j.algal.2012.05.001

[23] Z. Arbib, J. Ruiz, P. Álvarez-Díaz, C. Garrido-Pérez, J. Barragan and J. Perales. "Photobiotreatment: influence of nitrogen and phosphorus ratio in wastewater on growth kinetics of Scenedesmus obliquus". Int J Phytorem. Vol. 15, Issue 8, pp. 774-788. 2013. URL: https://doi.org/10.1080/15226 514.2012.735291

[24] M. Sacristán de Alva, V.M. Luna-Pabello, E. Cadena and E. Ortíz. "Green microalga Scenedesmus acutus grown on municipal wastewater to couple nutrient removal with lipid accumulation for biodiesel production". Bioresour Technol. Vol. 146, pp. 744-748. 2013. URL: https://doi.org/10.1016/j. biortech.2013.07.061

[25] M.-K. Ji, R.A. Abou-Shanab, S.-H. Kim, E.-S. Salama, S.-H. Lee, A.N. Kabra, Y.-S. Lee, S. Hong and B.-H. Jeon. "Cultivation of microalgae species in tertiary municipal wastewater supplemented with $\mathrm{CO} 2$ for nutrient removal and biomass production". Ecol Eng. Vol. 58, pp. 142-148. 2013. URL: https://doi.org/10.1016/j.ecoleng.2013.06.020

[26] H.-Y. Ren, B.-F. Liu, C. Ma, L. Zhao and N.-Q. Ren. "A new lipid-rich microalga Scenedesmus sp. strain R-16 isolated using Nile red staining: effects of carbon and nitrogen sources and initial $\mathrm{pH}$ on the biomass and lipid production". Biotechnol Biofuels. Vol. 6. 2013. URL: https://doi. org/10.1186/1754-6834-6-143

[27] F.-F. Chu, P.-N. Chu, X.-F. Shen, P.K. Lam and R.J. Zeng. "Effect of phosphorus on biodiesel production from Scenedesmus obliquus under nitrogen-deficiency stress".
Bioresour Technol. Vol. 152, pp. 241-246. 2014. URL: https://doi.org/10.1016/j. biortech.2013.11.013

[28] I. Pancha, K. Chokshi, B. George, T. Ghosh, C. Paliwal, R. Maurya and S. Mishra. "Nitrogen stress triggered biochemical and morphological changes in the microalgae Scenedesmus sp. CCNM 1077'. Bioresour Technol. Vol. 156, 146154. 2014. URL: https://doi.org/10.1016/j. biortech.2014.01.025

[29] M. Song, H. Pei, W. Hu, S. Zhang, G. Ma, L. Han and Y. Ji. "Identification and characterization of a freshwater microalga Scenedesmus SDEC-8 for nutrient removal and biodiesel production". Bioresour Technol. Vol. 162, pp. 129-135. 2014. URL: https:// doi.org/10.1016/j.biortech.2014.03.135

[30] F.K. El-Baz, S. Abdo, M. Abdo and G.H. Ali. "Enhancement of Oil Accumulation in Microalga Scenedesmus obliquus". International Journal of Pharmaceutical Sciences Review and Research. Vol. 21, pp. 110-115. 2015. URL: http://www. globalresearchonline.net/

[31] X.-F. Shen, J.-J. Liu, F.-F. Chu, P.K. Lam and R.J. Zeng. "Enhancement of FAME productivity of Scenedesmus obliquus by combining nitrogen deficiency with sufficient phosphorus supply in heterotrophic cultivation”. Appl Energy. Vol. 158, pp. 348354. 2015. URL: https://doi.org/10.1016/j. apenergy.2015.08.057

[32] A. Cicci and M. Bravi. "Fatty Acid Composition and Technological Quality of the Lipids Produced by the Microalga Scenedesmus dimorphus 1237 as a Function of Culturing Conditions". The Italian Association of Chemical Engineering. Vol. 49, pp. 181-186. 2016. URL: http:// doi.org/10.3303/CET1649031

[33] S.K. Gupta, F.A. Ansari, A. Shriwastav, N.K. Sahoo, I. Rawat and F. Bux. "Dual role of Chlorella sorokiniana and Scenedesmus obliquus for comprehensive wastewater treatment and biomass production for bio-fuels". J Cleaner Prod. Vol. 115, pp. 255264. 2016. URL: https://doi.org/10.1016/j. jclepro.2015.12.040

[34] K. Pérez, A. Vega, L. Hernández, D. Parra y M. Ballen-Segura. "Uso de Scenedesmus para 
la remoción de metales pesados y nutrientes de aguas residuales para la industria textil". Ingeniería solidaria. Vol. $12 \mathrm{~N}^{\circ}$ 20. 2016.

[35] M. Ballen-Segura, L. Hernandez, D. Parra, A. Vega and K. Pérez. "Using Scenedesmus sp. for the Phycoremediation of Tannery Wastewater". Tecciencia. Vol. 11, Issue 21, pp. 69-75. 2016.

[36] J. Folch, M. Lees and G. Sloane-Stanley. "A simple method for the isolation and purification of total lipids from animal tissues". J biol Chem. Vol. 226, Issue 1, pp. 497-509. 1956. URL: http://www.jbc. org/content/226/1/497.full.pdf

[37] S. Balaji, T. Kalaivani, C. Rajasekaran, M. Shalini, R. Siva, R.K. Singh and M.A. Akthar. "Arthrospira (Spirulina) species as bioadsorbents for lead, chromium, and cadmium-a comparative study". CLEAN-Soil, Air, Water. Vol. 42, Issue 12, pp. 17901797. 2014. URL: https://doi.org/10.1002/ clen. 201300478

[38] A.C. Redfield. "On the proportions of organic derivatives in sea water and their relation to the composition of plankton". university press of liverpool Liverpool, UK. 1934.

[39] E.G. Bligh and W.J. Dyer. "A rapid method of total lipid extraction and purification". Canadian journal of biochemistry and physiology. Vol. 37, Issue 8, pp. 911-917. 1959.

[40] M. Axelsson and F. Gentili. "A single-step method for rapid extraction of total lipids from green microalgae". PloS one. Vol. 9, Issue 2. 2014.

[41] E. Ryckebosch, K. Muylaert and I. Foubert. "Optimization of an analytical procedure for extraction of lipids from microalgae". Journal of the American Oil Chemists' Society. Vol. 89, Issue 2, pp. 189-198. 2012.

[42] Y. Li, M. Horsman, B. Wang, N. Wu and C.Q. Lan. "Effects of nitrogen sources on cell growth and lipid accumulation of green alga Neochloris oleoabundans". Appl Microbiol Biotechnol. Vol 81, Issu 4, pp. 629636. 2018. URL: https://doi.org/10.1007/ s00253-008-1681-1

[43] Q. Hu, M. Sommerfeld, E. Jarvis, M. Ghirardi, M. Posewitz, M. Seibert and A. Darzins. "Microalgal triacylglycerols as feedstocks for biofuel production: perspectives and advances". The Plant Journal. Vol. 54, Issue 4, pp. 621-639. 2008.

[44] L. Rodolfi, G. Chini Zittelli, N. Bassi, G. Padovani, N. Biondi, G. Bonini and M.R. Tredici. "Microalgae for oil: Strain selection, induction of lipid synthesis and outdoor mass cultivation in a low-cost photobioreactor". Biotechnology and bioengineering. Vol. 102, Issue 1, pp. 100-112. 2009.

[45] M. Takagi and T. Yoshida. "Effect of salt concentration on intracellular accumulation of lipids and triacylglyceride in marine microalgae Dunaliella cells". Journal of bioscience and bioengineering. Vol. 101, Issue 3, pp. 223-226. 2006.

[46] Y. Li, Y.-F. Chen, P. Chen, M. Min, W. Zhou, B. Martinez, J. Zhu and R. Ruan. "Characterization of a microalga Chlorella sp. well adapted to highly concentrated municipal wastewater for nutrient removal and biodiesel production". Bioresour Technol. Vol. 102, Issue 8, pp. 5138-5144. 2011. URL: https:// doi.org/10.1016/j.biortech.2011.01.091

[47] A. Illman, A. Scragg and S. Shales. "Increase in Chlorella strains calorific values when grown in low nitrogen medium". Enzyme Microb Technol. Vol. 27, Issue 8, pp. 631635. 2000. URL: https://doi.org/10.1016/ S0141-0229(00)00266-0

[48] Z.-Y. Liu, G.-C. Wang and B.-C. Zhou. "Effect of iron on growth and lipid accumulation in Chlorella vulgaris". Bioresour Technol. Vol. 99, Issue 11, pp. 4717-4722. 2008. URL: https://doi.org/10.1016/j. biortech.2007.09.073 